\title{
Laboratory investigation of coal characteristics from Tikak Parbat formation of North-East India for coal bed methane study
}

\author{
Prasun Banik ${ }^{1}$
}

Received: 7 February 2020 / Accepted: 28 July 2020 / Published online: 9 August 2020

(c) The Author(s) 2020

\begin{abstract}
The increasing demand for cleaner source of energy forces India to explore various energy sources, and in this process, coal bed methane gas attracts lot of attention for its favourable characteristics including abundance of coal, clean gas, mitigation of greenhouse gases, reduction in hazard in mines, etc. However, the challenge faced during exploration and production varies from depth of seam, heterogeneity in coal characteristics, rank, sorption capacity, saturation, etc. So the detail analysis of various properties is important for economical extraction of gas. The present paper investigates coal properties and their influence on coal bed methane potentiality. Samples from core wells have been analysed in laboratory using proximate and ultimate analyser. Linear correlations between coal constituents and vitrinite reflectance as well as sorption capacity of coal have been established statistically. Mutual relations among proximate parameters are developed.
\end{abstract}

Keywords Coal bed methane $\cdot$ Proximate analysis $\cdot$ Ultimate analysis $\cdot$ Vitrinite reflectance $\cdot$ Gas content

\section{Introduction}

Fossil fuel coal and natural gas have the largest share in the energy mix internationally. Traditionally, coal has been used as a fuel in industries that has proven abundance regionally. Switching from coal to natural gas for power generation would benefit the environment by producing less air pollutant and greenhouse gas emissions (Chabukdhara and Singh 2016). Coals in its matrix have entrapped methane gas, and this trapped methane gas has been found to be a promising alternative cleaner source of fossil fuel. This leads to extraction of methane gas from coal known as coal bed methane (CBM) for commercial utilization. CBM and natural gas both contain $95 \%$ of pure methane (Rice 1993; Levine 1993). Its heating value is approximately $8500 \mathrm{Kcal} / \mathrm{kg}$ compared to $9000 \mathrm{Kcal} / \mathrm{kg}$ of natural gas (Ojha et al, 2011).

In total, 33 CBM blocks have been awarded in four rounds of CBM bidding till date, out of which one block, namely AS-CBM-2008/IV, in North-East India has been awarded for exploration of CBM gas. According to Director General

Prasun Banik

prasunbanik@dibru.ac.in

1 Department of Petroleum Engineering, DUIET, Dibrugarh University, Dibrugarh 786004, India of Hydrocarbons, India, prognosticated CBM resources in North-East India are 8.5 billion cubic meter.

Assessment of CBM potentiality requires complete knowledge on characteristics of coal and its variation. This investigation reports proximate and ultimate parameters of coal samples collected from core holes drilled in the block and inferred vitrinite reflectance $\left(R_{o}(\%)\right)$ and sorption capacity $(\mathrm{cc} / \mathrm{g})$ of coal using empirical relations. The correlation of different proximate parameters with vitrinite reflectance and sorption capacity is established using statistical methods.

\section{Materials and methods}

\section{Sample collection and characterization}

The virgin coal samples of Tikak Parbat formation of Oligocene age were collected from two core wells drilled in the CBM block. Samples were prepared as per prescribed guideline [IS: 436 (Part 1/section 1)-1964]. The proximate analysis was carried out by following BIS standard 1350 (Part I), and elemental composition was determined using CHNS Euro EA Elemental analyser. The results of the proximate and elemental analyses are shown in Tables 1 and 2. 
Table 1 Results of proximate analysis

\begin{tabular}{lllllllllll}
\hline Bore hole no. & Depth $(\mathrm{m})$ & $\begin{array}{l}\mathrm{M} \\
\%\end{array}$ & $\begin{array}{l}\mathrm{A} \\
\%\end{array}$ & $\begin{array}{l}\mathrm{VM} \\
\%\end{array}$ & $\begin{array}{l}\mathrm{FC} \\
\%\end{array}$ & $\begin{array}{l}\text { A (d) } \\
\%\end{array}$ & $\begin{array}{l}\text { VM (d) } \\
\%\end{array}$ & FC (d) $\%$ & VM (daf) $\%$ & FC (daf) $\%$ \\
\hline \multirow{4}{*}{ BH1 } & 739.6 & 3.3 & 31.4 & 33.7 & 31.6 & 32.47 & 34.85 & 32.68 & 51.61 & 48.39 \\
& 740.5 & 4 & 14.09 & 43.43 & 38.48 & 14.68 & 45.24 & 40.08 & 53.02 & 46.98 \\
& 744 & 4.28 & 25.6 & 37.07 & 33.05 & 26.74 & 38.73 & 34.53 & 52.87 & 47.13 \\
& 746 & 4.2 & 39.1 & 32.5 & 24.2 & 40.81 & 33.92 & 25.26 & 57.32 & 42.68 \\
BH2 & 832.2 & 4.63 & 1.62 & 42.66 & 51.09 & 1.70 & 44.73 & 53.57 & 45.50 & 54.50 \\
& 837 & 5.19 & 1.66 & 40.44 & 52.71 & 1.75 & 42.65 & 55.60 & 43.41 & 56.59 \\
& 839 & 5.42 & 5.15 & 47.15 & 42.28 & 5.45 & 49.85 & 44.70 & 52.72 & 47.28 \\
& 846 & 4.84 & 1.64 & 40.81 & 52.71 & 1.72 & 42.89 & 55.39 & 43.64 & 56.36 \\
\hline
\end{tabular}

M\% moisture present percentage, A\% ash present percentage, VM\%, volatile matter present percentage, FC\% fixed carbon present percentage, $\mathrm{A}(\mathrm{d}) \%$ ash present in dry basis, $\mathrm{VM}(\mathrm{d}) \%$ volatile matter present percentage in dry basis, $\mathrm{FC}(\mathrm{d}) \%$ fixed carbon present percentage in dry basis, $\mathrm{VM}(\mathrm{daf}) \%$ volatile matter present percentage in dry ash-free basis, $\mathrm{FC}(\mathrm{daf}) \%$ fixed carbon present percentage in dry ash-free basis

Table 2 Results of ultimate analysis and other parameters of coal samples

\begin{tabular}{llllllll}
\hline Bore hole no. & Depth $(\mathrm{m})$ & $\mathrm{C} \%$ & $\mathrm{H} \%$ & $\mathrm{~S} \%$ & Fuel ratio & $\mathrm{H} / \mathrm{C}$ ratio & $\mathrm{R}_{\mathrm{o}} \%$ \\
\hline \multirow{4}{*}{ BH 1 } & 739.6 & 52.647 & 4.179 & 0.462 & 0.938 & 0.079 & 0.447 \\
& 740.5 & 48.547 & 4.215 & 0.471 & 0.886 & 0.087 & 0.415 \\
& 744 & 53.940 & 4.098 & 0.459 & 0.892 & 0.076 & 0.419 \\
& 746 & 62.327 & 4.163 & 0.518 & 0.745 & 0.067 & 0.323 \\
BH 2 & 832.2 & 68.919 & 5.334 & 2.792 & 1.198 & 0.077 & 0.595 \\
& 837 & 81.976 & 4.967 & 2.359 & 1.303 & 0.061 & 0.651 \\
& 839 & 62.182 & 5.053 & 2.678 & 0.897 & 0.081 & 0.422 \\
& 846 & 67.829 & 5.113 & 0.521 & 1.292 & 0.075 & 0.645 \\
& 847 & 58.866 & 4.630 & 4.630 & 0.977 & 0.079 & 0.471 \\
\hline
\end{tabular}

$\mathrm{C} \%$ carbon present percentage, $\mathrm{H} \%$ hydrogen present percentage, $\mathrm{S} \%$ sulphur present percentage, $\mathrm{R}_{\mathrm{o}} \%$ vitrinite reflectance value

\section{Petrographic analysis}

It describes the characteristics of coal on the basis of chemical composition. Petrographic study (proximate analysis and ultimate analysis) helps in determination of rank and sorption capacity of coal required in evaluation of methane gas potential of coal seams. Proximate analysis provides coal composition in terms of organic and inorganic constituents. Fixed carbon and volatile matter are organic constituents, while inorganic constituents are moisture and ash. Ultimate analysis gives elemental composition of coal. The results of two analyses are evaluated to know suitability of coal samples for CBM.

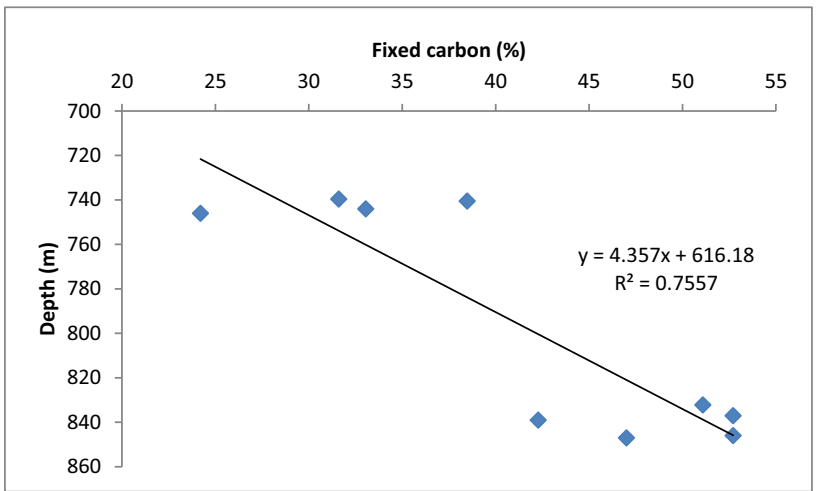

Fig. 1 Variation in fixed carbon with depth

\section{Result and discussion}

\section{Coal quality analysis}

Proximate analyses of the investigated coal samples reveal 
that the fixed carbon varies from 24.2 to $52.71 \%$ (Table 1) and trend shows fixed carbon increases with depth (Fig. 1). Coal maturation has increasing trend with depth, and similar observation was reported elsewhere (Laxminarayana and Crosdale 1999). Volatile matter is in between 32.5 and $48.1 \%$. It indicates high volatile bituminous coal (Averitt and Berryhill 1950). Fuel ratio of coal is the ratio between volatile matter and fixed carbon content. As the fuel ratio is in between 0.745 to 1.303 (Table 2), the coal can be termed as bituminous coal according to the Fraser's classification (1877). A similar observation was also reported for the determination of rank of Bapung coal, India. Ash content in bore hole 1 samples varied from 14.09 to $39.1 \%$, while borehole 2 samples contain $1.1 \%$ to $5.15 \%$ ash and moisture content varies from 3.3 to $5.42 \%$. It shows quality of coal is good enough to have methane gas for production.

From ultimate analysis result, it is found that the carbon percentage varies from 48.547 to $68.919 \%$ except one sample that has high carbon content of $81.976 \%$ (Table 2). The sulphur content is high, and the percentage varies from 0.459 to 4.630. Variation in $\mathrm{H}: \mathrm{C}$ ratio from 0.061 to 0.087 confirms bituminous coal (Table 2). A similar observation was described for US coal classification elsewhere (Campbell 1904). Bituminous-type coals are good candidature for CBM.

\section{Rank of coal under study}

The value of vitrinite reflectance steadily increases with maturity of coal, and coal rank is generally determined by it. In the present study, vitrinite reflectance is calculated using the correlation between volatile matter and vitrinite reflectance proposed by Rice 1993. The formula is as follows:

$R_{o} \%=-2.712 \times \log \left(V M_{(\mathrm{daf})}\right)+5.092$

where $R_{o} \%$ is vitrinite reflectance $(\%), \mathrm{VM}_{\text {(daf) }}$ is volatile matter (dry ash-free basis) (\%).

It is observed that the vitrinite reflectance values of samples are in between 0.415 and $0.651 \%$ except one sample that has low value $0.323 \%$ at $746 \mathrm{~m}$ and the highest value is $0.651 \%$ at $837 \mathrm{~m}$ depth (Table 2). Hence, it indicates that coal samples belong to subbituminous to bituminous rank according to rank parameter discussed elsewhere (Diesel 1992).

It can be inferred from proximate, ultimate analysis and coal rank result that there is a trend of increase in vitrinite reflectance value with depth of coal (Trent et al. 1982). A similar observation was reported in the German Creek and Moranbah Coal Measures in Australia for macerals study elsewhere (Ward et al., 2005). Detail studies reveal that vitrinite reflectance increases with increase in fixed carbon (dry ash-free basis) and decrease in percentage of volatile matter (dry ash-free basis) (Tables 1, 2). The similar observations were reported elsewhere (Grieve 1997; Langenberg et al., 1992; Ward et al. 2005; Kumar et al., 2015). There is an increase in carbon content with vitrinite reflectance value (Table 2) except at $746 \mathrm{~m}$ depth. These coal characteristics indicate towards good quantity of methane gas accumulation for exploitation.

\section{Estimation of gas content in coal}

Most of the gases in coal remain on the internal surface of micropores in adsorbed condition. Earlier researchers, Pophare et al. (2008), have shown that the sorption capacity of coal varies directly with pressure and inversely with temperature. Kim 1977 had developed a correlation between volume of adsorbed gas with pressure and temperature and proximate analysis values. Kim's empirical equation is stated as follows

$G_{\text {saf }}=0.75 \times\lfloor 1-A-M\rfloor \times\left\lfloor K\left(P^{N}\right)-0.14 \times\langle 1.8 D \mid 100\rangle\right\rfloor$

where $\mathrm{G}_{\text {saf }}$ is dry, ash free gas storage capacity $(\mathrm{cc} / \mathrm{g}), \mathrm{M}$ is moisture content (\%), A is ash content (\%), D is depth of sample (m)

$N=$ Constant $=0.315-0.01 \times \frac{F C_{\mathrm{daf}}}{V M_{\mathrm{daf}}}$

where $\mathrm{FC}_{\mathrm{daf}}$ is fixed carbon (dry ash-free basis) (\%), $\mathrm{VM}_{\mathrm{daf}}$ is volatile matter (dry ash-free basis) $(\%)$

$K=0.8 \times \frac{F C_{\mathrm{daf}}}{V M_{\mathrm{daf}}} \times 5.6$

$P=P_{\text {hyd }}=0.096 \times D($ atm. $)$

The adsorbed gas content as determined by the above equation is shown in Table 3. The gas content varies from 9.0011 to $13.1510 \mathrm{~g} / \mathrm{cc}$ in borehole 1 , while it is in between $14.8146 \mathrm{cc} / \mathrm{g}$ and $16.0664 \mathrm{~g} / \mathrm{cc}$ in bore hole 2 . The values indicate good potentiality of CBM in the block (Tunio et al. 2014). The range is much more than the threshold value of $8.5 \mathrm{cc} / \mathrm{g}$ of gas for economic viability of CBM (Mukherjee et al. 1999).

\section{Linear correlation between gas content and composition of coal}

In the present study, the correlation of different proximate and ultimate parameters with gas content of coal is established using statistical methods and is shown in Figs. 2, 3,4 . Moisture and ash have adverse effect on adsorption capacity of methane in coal. From the literature review 
Table 3 Calculated gas storage capacity and non-coal content

\begin{tabular}{lllllll}
\hline Bore hole no. & Depth $(\mathrm{m})$ & $\mathrm{N}$ & $\mathrm{K}$ & $\mathrm{P}(\mathrm{atm})$. & $\begin{array}{l}\text { Gas storage } \\
\text { capacity (cc/g) }\end{array}$ & $\begin{array}{l}\text { (Ash + moisture } \\
\text { content) fraction }\end{array}$ \\
\hline \multirow{3}{*}{ BH1 } & 739.6 & 0.30562 & 6.35015 & 71.00 & 10.5304 & 0.347 \\
& 740.5 & 0.30614 & 6.30882 & 71.09 & 13.1510 & 0.181 \\
& 744 & 0.30608 & 6.31325 & 71.42 & 11.2768 & 0.299 \\
& 746 & 0.30755 & 6.19569 & 71.62 & 9.0011 & 0.433 \\
$\mathrm{BH} 2$ & 832.2 & 0.30302 & 6.55809 & 79.89 & 15.9160 & 0.063 \\
& 837 & 0.30197 & 6.64273 & 80.35 & 15.9780 & 0.069 \\
& 839 & 0.30603 & 6.31737 & 80.54 & 14.8146 & 0.106 \\
& 846 & 0.30208 & 6.63328 & 81.22 & 16.0664 & 0.065 \\
& 847 & 0.30523 & 6.38170 & 81.31 & 15.9042 & 0.049 \\
\hline
\end{tabular}

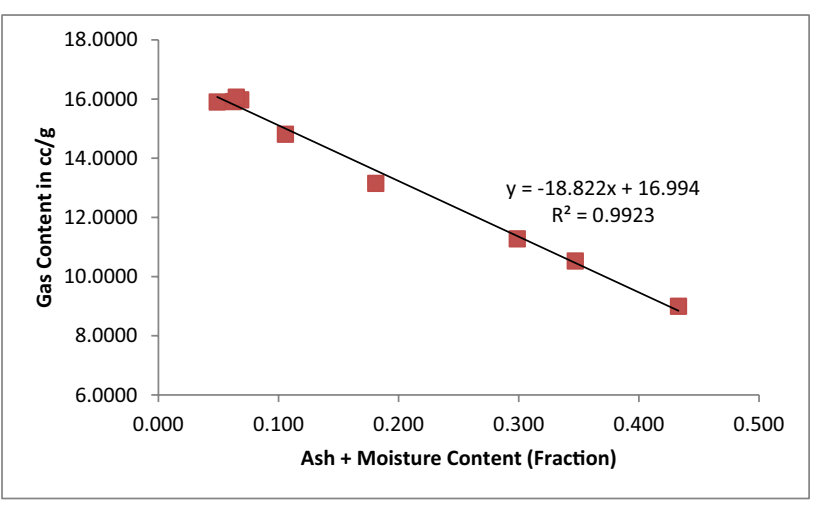

Fig. 2 Relation between gas content and (ash + moisture) content

(Ojha et al. 2011), it is found that $1 \%$ and $5 \%$ of moisture content in coal reduce the sorption capacity by $25 \%$ and $65 \%$, respectively. Figure 2 shows the similar trend where reduction in gas sorption capacity of coal happens due to increase in ash and moisture fraction.

Gas content increases with increase in fixed carbon (dry ash-free basis) (Fig. 3a). A similar observation was made while studying coals of US coal classification elsewhere (Kim, 1977). Ultimate analysis result shows that gas content increases with carbon content (Fig. 3c). This progressive increment in gas content with carbon shows the potentiality of coal seams. This poor correlation may be explained in a way that the gas content increases slowly at low carbon content stage (Cheng et al. 2017). Another encouraging fact is that gas content decreases with increase in volatile matter (dry ash free) (Fig. 3b). Similar observation is made elsewhere (Yuanping Cheng et al. 2017). The reason is when volatile matter decreases gradually, methane gas adsorbs itself in vacated space in coal matrix, and this confirms the viability of CBM in coal seams. From the above study, it is observed that with an increase in vitrinite reflectance and depth of occurrence of coal, the gas content increases (Fig. 4a, b). Similar observations are made elsewhere (Ryan 1992; Pophare et al.
2008; Karmakar et al. 2013; Panwar et al. 2017; Kumar et al. 2015). It can be concluded from coal properties linear relationships that coal is inferred to have good enough methane gas in its seams.

With the increase in buried depth, pressure and temperature increase and plant material undergoes coalification in anaerobic condition. Thus, coals become progressively enriched in carbon and simultaneously continue to expel volatile matters. It leads to progressively enriched methane content with the enhancement of thermal maturation as depth of overburden increases. Thus, adsorption capacity of coal is increasing and the adsorption ability of methane is enhanced.

Methane gas released during maturation is adsorbed on the pores of coal (Mandal et al. 2004). Low-rank coals have strong adsorption capacity due to its high porosity value. Micropores and transition pores are the primary accumulation space for methane adsorption. The methane gas desorption is affected by macropores and mesopores during production (Fan et al. 2012).

\section{Conclusions}

Proximate and ultimate analyses are primarily carried out to assess the coal characteristics suitable for CBM. Studied coal samples show good gas holding capacity, and there is an increasing trend of gas holding capacity with fixed carbon as well as vitrinite reflectance value. Non-organic constituents have an adverse effect on methane content. The rank of coal samples is inferred to be subbituminous to bituminous. Coal samples occur at a depth range of 700-850 m suitable for artificial lift system installation for dewatering coal seams. It is also found that gas content, vitrinite reflectance and carbon content values increase with depth which reflects suitability for development of CBM. The hydrocarbon generation, rank and depth of occurrence of coal make it prospective for CBM exploration and further investigation. 
(a)

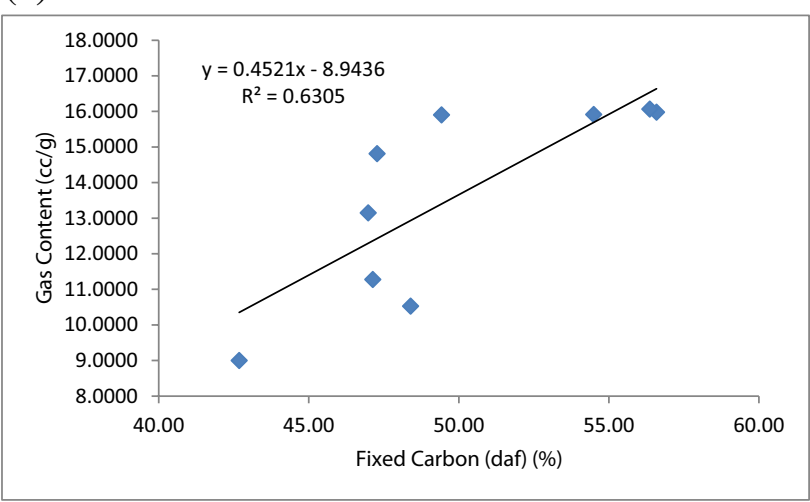

(b)

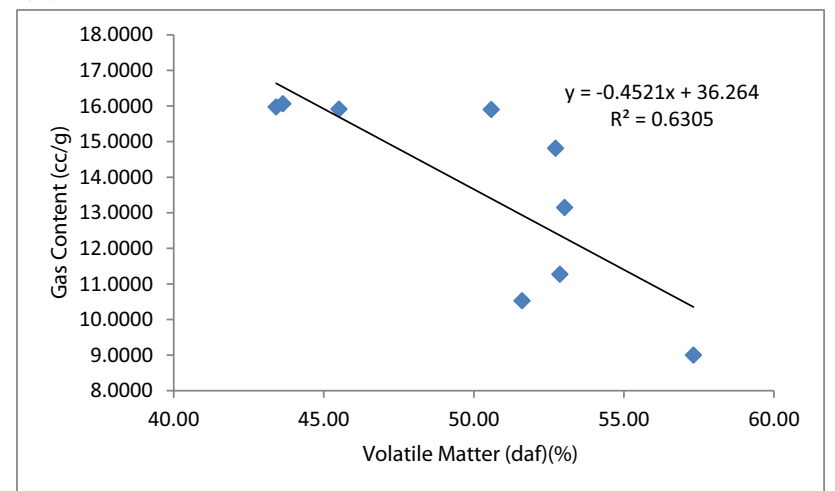

(c)

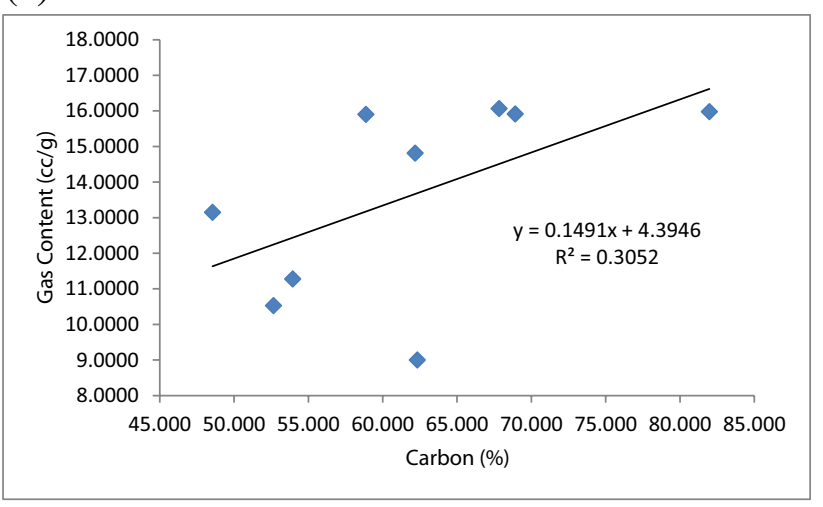

Fig. 3 a Variation in gas content with fixed carbon (dry ash free). b Variation in gas content with volatile matter (dry ash free). c Variation in gas content with carbon percentage

The present investigation work will be continued on large scale using multiple depth samples to consolidate the current results. In future, extensive laboratory study on adsorption isotherm curve and pore structure and its distribution will be carried out to understand the critical (a)

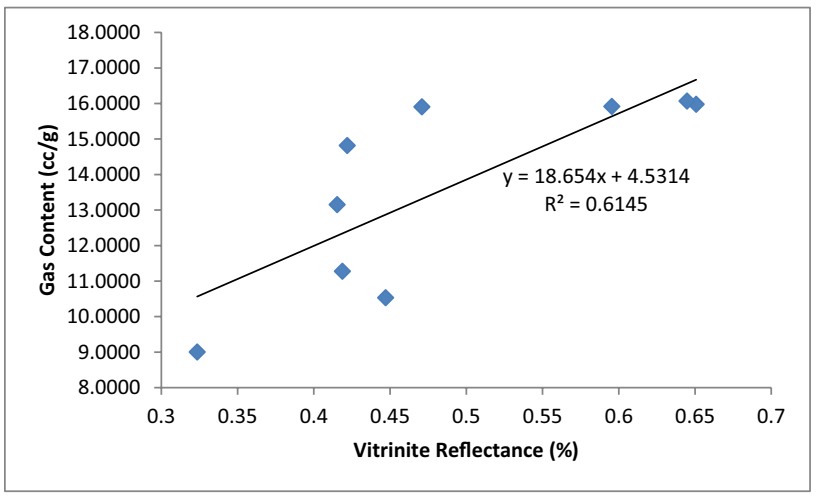

(b)

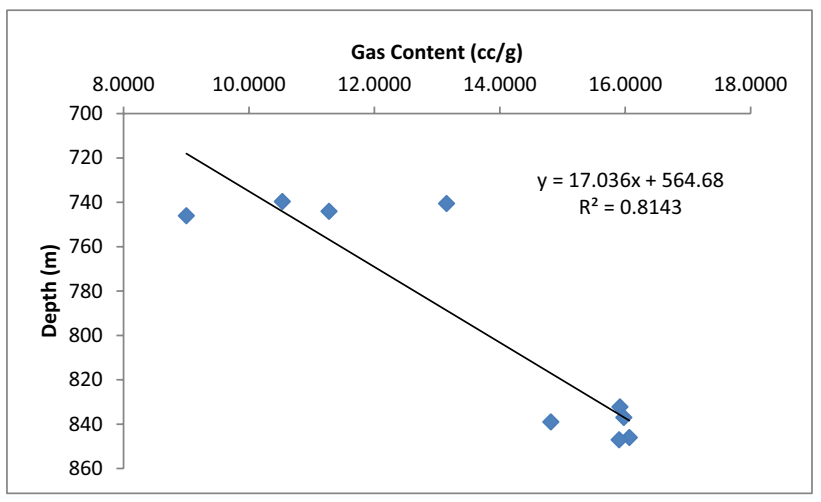

Fig. 4 a Variation in gas content with vitrinite reflectance. b Variation in gas content with depth

reservoir parameters for evaluation of commercial viability of CBM.

Acknowledgements The author sincerely thanks two anonymous reviewers for their kind comments and useful suggestions. Author is grateful to Prof. Minati Das, Dean, Dibrugarh University for her continuous encouragement.

Open Access This article is licensed under a Creative Commons Attribution 4.0 International License, which permits use, sharing, adaptation, distribution and reproduction in any medium or format, as long as you give appropriate credit to the original author(s) and the source, provide a link to the Creative Commons licence, and indicate if changes were made. The images or other third party material in this article are included in the article's Creative Commons licence, unless indicated otherwise in a credit line to the material. If material is not included in the article's Creative Commons licence and your intended use is not permitted by statutory regulation or exceeds the permitted use, you will need to obtain permission directly from the copyright holder. To view a copy of this licence, visit http://creativecommons.org/licenses/by/4.0/.

\section{References}

Averitt P, Berryhill LR (1950) Coal resources of the United States, a progress report, geological survey circular 94 
Campbell MR (1904) Report on operation of coal testing plant of the USGS In: United States geological survey at the louisiana purchase exposition, St. Louis, MO, p 48

Chabukdhara M, Singh OP (2016) Coal mining in northeast India: an overview of environmental issues and treatment approaches. Int $\mathrm{J}$ Coal Sci Technol 3(2):87-96

Cheng Y, Jiang H, Zhang X, Cui J, Song C, Li X (2017) Effects of coal rank on physicochemical properties of coal and on methane adsorption. Int J Coal Sci Technol 4(2):129-146. https://doi. org/10.1007/s40789-017-0161-6

Diessel CFK (1992) Coal-bearing depositional systems. Springer, Berlin, $\mathrm{p} 721$

Fan J, Ju Y, Hou Q, Wu Y, Li X (2012) Characterization of coal reservoirs in two major coal fields in Northern China: implications for Coalbed methane development. J Geol Res. https://doi. org/10.1155/2012/2701306

Frazer P Jr (1877) Classification of coals. Am Inst Min Eng 6:430

Grieve DA (1997) Relationships between Coal Quality parameters in British Columbia Coals. Br Columbia Geol Survey Geol Fieldwork 1:47-66

Indian standard methods for sampling of coal and coke, IS: 436 (Part 1/Set 1)-1964

Karmakar B, Ghosh T, Ojha K, Pathak AK, Devraju J (2013) Effects of chemical composition and petrography of coal for coalbed methane evaluation with special reference to in situ gas content. In: 10th Biennial international conference and exposition, pp 1-5

Kim GA (1977) Estimating methane content of bituminous coalbeds from adsorption data. U.S. Bureau of Mines RI8245, pp 1-22

Kumar H, Mishra S, Mishra MK, Parida A (2015) Petrographical characteristics of bituminous coal from Jharia Coalfield India: it's implication on coal bed methane potentiality. Procedia Earth Planet Sci 11:38-48

Langenberg Willem, Macdonald Don, Kalkreuth Wolfgang (1992) Sedimentologic and tectonic controls on coal quality of a thick coastal plain coal in the foothill of Alberta, Canada. Geol Soc Am 267:101-116

Laxminarayana C, Crosdale PJ (1999) Role of coal type and rank on methane sorption characteristics of Bowen basin, Australia coals. Int J Coal Geol 40:309-325

Levine JR (1993) Coalification: the evolution of coal as a source rock and reservoir rock for oil and gas. Am Assoc Petrol Geol Stud Geol 38:39-77
Mandal D, Tewari DC, Rautela MS (2004) Analysis of micro-fractures in coal for coal bed methane exploitation in Jharia coal field. In: 5th Conference and exposition on petroleum geophysics, Hyderabad, India, pp 904-909

Mukherjee PK, Sinha DP, Rawat DS (1999) Coal bed methane: how India fits as a potential candidate in CBM prospect and potentiality. SAAEG, pp 79-87

Ojha K, Karmakar B, Mandal A, Pathak AK (2011) Coal bed methane in India: difficulties and prospects. Int J Chem Eng Appl 2:256-260

Panwar DS, Saxena VK, Chaurasia RC, Singh AK (2017) Prospective evaluation of coal bed methane in Raniganj coal field, India. Energy Sources Part A: Recovery Utilization Environ Effects 39:946-954

Pophare AM, Mendhe VA, Varade AM (2008) Evaluation of coal bed methane potential of coal seams of Sawang Colliery, Jharkhand, India. J Earth Syst Sci 117:121-132

Rice DD (1993) Composition and origins of coalbed gas. Am Assoc Pet Geol Stud Geol 38:159-184

Ryan DB (1992) An equation for estimation of maximum coalbedmethane resource potential. Geological Fieldwork 1991, British Columbia Geological Survey Branc, Paper 1992-1

Trent VA, Medlin JH, Lynn Coleman S, Stanton RW (1982) Chemical analyses and physical properties of 12 coal samples from the Pochontas field, Tazewell County, Virginia, and McDowell County, West Virginia. Geological Survey Bulletin 1528

Tunio SQ, Bhattacharya SK, Irawan S, Kyaw A (2014) Investigating methane adsorption potential of malaysian coal for coal bed methane (CBM) study. Mediterr J Soc Sci 5(27):178

Ward CR, Li ZS, Gurba LW (2005) Variations in coal maceral chemistry with rank advance in the German Creek and Moranbah Coal Measures of the Brown Basin, Australia, using electron microprobe techniques. Int J Coal Geol 63:117-129

Publisher's Note Springer Nature remains neutral with regard to jurisdictional claims in published maps and institutional affiliations. 